\section{The vignette for V15 N3 issue}

Published online: 9 April 2008

(C) National Science Council Taipei 2008

\section{Immunotherapy for head and neck cancer}

In the current review by $\mathrm{Wu}$ et al. [1], recent advances as they pertain to therapeutic intervention of human head and neck cancer are described. The authors started by describing tumor-specific antigens that are unique to head and neck cancers. Using these tumor-specific antigens as targets, a comprehensive coverage of beneficial immune responses is presented. With estimated 600,000 cases of head and neck cancer cases annually in the world and the relative lack of effective treatment, this review is not only timely but also brings into the picture on-going as well as potentially exciting treatment directions.

\section{Antiviral activity of pyridyl imidazolidinones against enterovirus 71 variants}

Enterovirus 71 (EV71) has emerged as the major causative agent of hand-foot-and-mouth disease (HFMD) fatalities worldwide, and it has also been associated with severe neurological diseases. For example, there was a large-scale HFMD outbreak in 1998 in Taiwan with 78 deaths [2]. Pyridyl imidazolidinones have previously been described as a novel class of EV71-selective inhibitors [3]. These compounds bind in a hydrophobic pocket of the viral VP1 capsid protein, which can acquire resistance mutations. The current study by Chen et al. [4] provides a comprehensive analysis of the effect of 11 drug variants on VP1-mutated EV71 variants. It confirms the importance of hydrophobic forces and the fit into the hydrophobic pockets of VP1 for drug efficacy. Whereas amino acid substitutions at VP1 position 192 can provide resistance, some drugs were identified that remain active on this VP1 variant.

\section{Expression and membrane integration of SARS-CoV M protein}

SARS-associated coronavirus (SARS-CoV) is a new member of coronavirus family. Infection of SARS-CoV causes severe acute respiratory syndrome (SARS), which is an emerging infectious disease and characterized by a cascade of immunological events leading to pulmonary inflammation and respiratory failure [5]. Expression of $\mathrm{M}$ and $\mathrm{E}$ proteins of SARS-CoV in insect cells is able to form virus-like particles, indicating that the $\mathrm{M}$ protein plays a crucial role in virion assembly [6]. Ma et al. [7] demonstrates that the translated products of $\mathrm{M}$ protein contain full-length un-glycosylated and glycosylated protein. The glycosylation of $\mathrm{M}$ protein occurs co-translationally in the presence of microsomes. The second and third transmembrane regions (a.a. 46-68 and 78-100) are able to insert a cytoplasmic protein into the endoplasmic reticulum membrane more efficiently than the first one (a.a. 14-36).

\section{Morphogenesis of hepatitis B vrion and subviral particles in the liver of transgenic mice}

Infection of human hepatitis B virus (HBV), a hepatotropic non-cytopathic DNA virus, causes acute hepatitis. Persistent human hepatitis B viral infection leads to a high risk of developing chronic hepatitis, cirrhosis, and hepatocellular carcinoma. Three different kinds of viral and subviral particles are present in patients' sera. The 42-nm Dane particle, infectious virion, is composed of a 31-nm nucleocapsid with genome inside and a lipid bilayer envelope containing large, middle and major (small) surface antigens. The 22-nm subviral spherical and filamentous 
particles, which are 1,000- to 10,000-fold excess of Dane particles, do not contain nucleocapsid. However, electron microscopy (EM) studies on the morphogenesis of these particles are few due to the low rate of virion production in livers and transfected cells [8]. Liou et al. [9] described the morphogenesis of HBV virion and subviral particles in the liver of transgenic mice using cryo-ultrathin section EM. Their results demonstrate that the morphogenesis of virions and subviral particles are through two separate pathways.

\section{Discovering implicit protein-protein interactions in the cell cycle using bioinformatics approaches}

The high throughput experimentation on genome-wide scale has generated enormous data. To develop bioinformatic tools are urgently needed to identify critical information to extract useful biological messages for life scientists to design appropriate experiments. Recently, several developments in text-mining tools have been made to automatically extract information from free-excess database such as PubMed [10, 11]. BioMap is an integrated software system that performs basic literature mining tasks on Medline database [12]. Palakal et al. [13] developed several new features as well as a new interface for BioMap. They used cdc2 interacting protein in Xenopus laevis as an example to show that this new version of BioMap indeed generated more homologue sequences for interacting proteins for $\mathrm{cdc} 2$ and suggested that these results are more reliable and are also consistent with the public domain software.

\section{Inhibitory role of TGIF in the $\mathrm{As}_{2} \mathrm{O}_{3}$-regulated p21WAF1/CIP1 expression}

Arsenic has been reported to be a chemotherapeutic agent for patients with acute promyelocytic leukemia by inhibiting cell growth and triggering apoptosis. In the present study it was found that $\mathrm{AS}_{2} \mathrm{O}_{3}$-induced c-Jun (Ser 63/73) phosphorylation can recruit TGIF/HDAC1 to the SP-1 binding sites and suppress p21 promotor activation [14]. It suggests that after $\mathrm{AS}_{2} \mathrm{O}_{3}$ treatment, the $\mathrm{N}$-terminal domain of c-Jun phosphorylation by JNK recruits TGIF/HDAC1 to the SPI sites and then represses p21 expression. Therefore, TGIF is involved in $\mathrm{AS}_{2} \mathrm{O}_{3}$-inhibited $\mathrm{p} 21$ expression, and then blocks the cell cycle arrest.

\section{The transcriptional factor Snail simultaneously triggers cell cycle arrest and migration of human hepatoma HepG2 cells}

Several transcriptional factors including Snail have been shown to induce epithelial-mesenchymal transition (EMT) and to repress expression of E-cadherin in many human carcinomas [15]. Activation of protein kinase $\mathrm{C}$ by phorbol ester can induce expression of Snail in human melanoma cells [16]. Hu et al. [17] provides experimental evidence suggesting that Snail is not only upregulated by phorbol ester in human hepatoma HepG2 cells but also is responsible for phorbol-ester-induced expression of cell cycle G1 inhibitor p15INK4b. This interesting result is contradictory to the recent observations that Snail is required for tumor growth and lymph node metastasis of human breast carcinoma cells [18]. Whether Snail plays a different role with respect to growth control in human hepatoma cells deserves more vigorous investigations.

\section{Lysophosphatic acid induces IL-1 $\beta$ expression in macrophages}

Lysophosphatic acid (LPA) is known to regulate inflammation and atherosclerosis by binding to its cognate receptors. Recent studies demonstrated that LPA is an important regulator of atherosclerosis by activating monocytic cells [19] and inducing neointimal formation in a rat carotid artery model [20]. Chang et al. [21] studied the effect of LPA on the upregulation of IL- $1 \beta$ expression in mouse J744a.1 macrophages. Gi/Rho activation and subsequent reactive oxygen species production were involved in LPAinduced expression of IL-1 $\beta$. The LPA-induced expression of IL- $1 \beta$ was also observed in human primary macrophages. These results suggested that LPA regulates inflammationrelated functions in both mouse and human macrophages.

\section{In situ delivery of stem cells in hypertensive rats}

Ischemic heart disease is the leading cause of death worldwide and also an important cause of heart failure [22]. The aim of the present study was to evaluate the effects of two different kinds of adult stem cell populations, administered in situ, on cardiac morphology, function and histology of SHR submitted to surgical coronary occlusion, in an attempt to investigate this therapeutic approach in a more physiological animal model of myocardial infarction. Results of this study demonstrated that the treatment with MSC and BMC groups had significantly reduced lesion tissue score, increased capillary density and normal (not-atrophied) myocytes, as compared to $\mathrm{NM}$ and $\mathrm{C}$ groups. The survival rate was higher in C, NM and MSC groups as compared to MI and BM groups. In situ injection of both MSCs and BMCs resulted in improved cardiac morphology, in a more physiological model of myocardial infarction represented by surgical coronary occlusion of spontaneously 
hypertensive rats. Only treatment with MSCs, however, ameliorated left ventricle dysfunction, suggesting a positive role of these cells in heart remodeling in infarcted hypertensive subjects [23].

\section{Isoeugenodilol inhibits neointimal formation}

Abnormal vascular smooth muscle cell (VSMC) proliferation within the arterial intima plays a key role in the progression of atherosclerotic lesions, hypertension, and restenosis [24]. Thus, this study was to determine the efficacy and the possible mechanism of action of the synthesized drug isoeugenodilol (a new third-generation $\beta$ adrenoceptor blocker) on the growth factor-induced proliferation of cultured rat vascular smooth muscle cells (VSMCs) and neointimal formation in a rat carotid arterial balloon injury model. Results demonstrated that isoeugenodilol shows an inhibitory effect on neointimal formation due to inhibition of both migration and proliferation of VSMCs. This study suggests that isoeugenodilol has potential for the prevention of atherosclerosis and restenosis [25].

\section{Methamphetamine-elicited alterations of dopamine- and serotonin-metabolite levels within $\mu$-opioid receptor knockout mice: a microdialysis study}

Methamphetamine (MA) is a powerful psychostimulant. A number of studies have indicated that $\mu$-opioid receptor $(\mu$ OR) can regulate the behavioral effects of MA on locomotor activity and behavioral sensitization [26, 27]. However, little is known regarding the role of $\mu$-OR on the alteration of neurotransmitter dopamine (DA)/serotonin (5HT) metabolism induced by MA. In this communication, Lan et al. [28] reported that $\mu$-opioid receptors play a critical role in regulation of MA-induced alterations of the extracellular concentration of DA and 5-HT metabolites in the mouse striatum. These findings may have important neurochemical implications regarding the role of the $\mu$ opioid receptors in MA-induced behavioral changes.

\section{Gastroprotective effect of leptin in indomethacin- induced gastric injury}

Gastric injuries associated with the use of nonsteroid antiinflammatory drugs (NSAIDs) are common occurrences. So far, the main treatments for these complications are the suppression of acid secretion, the use of prostaglandin analogues and cyclooxygenase-2 (COX-2) inhibitors. However, this gastropathy has also been reported to be caused by neutrophil activation, leading to the production of reactive oxygen species (ROS) and nitric oxide (NO). Recently, leptin has been reported to have protective effects in several gastric injuries. This study [29] examined the gastroprotective effects of leptin in indomethacininduced gastric ulcer and found that it did have protective effects through the production of mucin and induction of SOD (superoxide dismutase) and glutathione peroxidase. These results suggest that leptin can prevent indomethacininduced injury through interfering with neutrophil infiltration, NO production and oxidative stress. This study offers a potential new preventive measure against NSAIDsassociated side effects.

\section{References}

1. Wu AA, Niparko KJ, Pai SI (2008) Immunotherapy for head and neck cancer. J Biomed Sci 15. doi:10.1007/s11373-008-9247-X

2. AbuBakar S, Chan YF, Lam SK (2000) Outbreaks of enterovirus 71 infection. N Engl J Med 342:355-356

3. Sawyer MH (1999) Enterovirus infections: diagnosis and treatment. Pediatr Infect Dis J 18:1033-1039

4. Chen TC, Liu SC, Huang PN, Chang HY, Chern JH, Shih SR (2008) Antiviral activity of pyridyl imidazolidinones against enterovirus 71 variants. J Biomed Sci 15. doi:10.1007/s11373007-9228-5

5. Lai MM (2003) SARS virus: the beginning of the unraveling of a new coronavirus. J Biomed Sci 10:664-675

6. Ho Y, Lin PH, Liu CY, Lee SP, Chao YC (2004) Assembly of human severe acute respiratory syndrome coronavirus-like particles. Biochem Biophys Res Commun 318:833-838

7. Ma HC, Fang CP, Hsieh YC, Chen SC, Li HC, Lo SY (2008) Expression and membrane integration of SARS-CoV M protein. $\mathrm{J}$ Biomed Sci 15. doi:10.1007/s11373-008-9235-1

8. Bruss V (2007) Hepatitis B virus morphogenesis. World J Gastroenterol 13:65-73

9. Liou W, Sung YJ, Tao MH, Lo SJ (2008) Morphogenesis of hepatitis B vrion and subviral particles in the liver of transgenic mice. J Biomed Sci 15. doi:10.1007/s11373-007-9221-z

10. Jang H, Lim J, Lim JH, Park SJ, Lee KC, Park SH (2006) Finding the evidence for protein-protein interactions from PubMed abstracts. Bioinformatics 22:e220-e226

11. Li X, Chen H, Huang Z, Su H, Martinez JD (2007) Global mapping of gene/protein interactions in PubMed abstracts: a framework and an experiment with P53 interactions. J Biomed Inform 40:453-464

12. Palakal M, Mukhopadhyay S, Stephens M (2005) Identification of biological relationships from textdocuments. In: Chen $\mathrm{H}$ (ed) Medical informatics: advances in knowledge management and datamining in biomedicine. Kluwer Publishers, p 449

13. Palakal M, Sebastian T, Stocum DL (2008) Discovering implicit protein-protein interactions in the cell cycle using bioinformatics approaches. J Biomed Sci 15. doi:10.1007/s11373-007-9231-x

14. Liu ZM, Huang HS (2008) Inhibitory role of TGIF in the $\mathrm{As}_{2} \mathrm{O}_{3}$ regulated p21WAF1/CIP1 expression. J Biomed Sci 15. doi: 10.1007/s11373-007-9232-9

15. Peinado H, Olmeda D, Cano A (2007) Snail, Zeb and bHLH factors in tumour progression: an alliance against the epithelial phenotype? Nat Rev Cancer 7:415-428

16. Dissanayake SK, Wade M, Johnson CE, O'Connell MP, Leotlela PD, French AD, Shah KV, Hewitt KJ, Rosenthal DT, Indig FE, 
Jiang Y, Nickoloff BJ, Taub DD, Trent JM, Moon RT, Bittner M, Weeraratna AT (2007) The Wnt5A/protein kinase C pathway mediates motility in melanoma cells via the inhibition of metastasis suppressors and initiation of an epithelial to mesenchymal transition. J Biol Chem 282:17259-17271

17. Hu CT, Wu JR, Chang TY, Cheng CC, Wu WS (2008) The transcriptional factor Snail simultaneously triggers cell cycle arrest and migration of human hepatoma HepG2. J Biomed Sci 15. doi:10.1007/s11373-007-9230-y

18. Olmeda D, Moreno-Bueno G, Flores JM, Fabra A, Portillo F, Cano A (2007) SNAI1 is required for tumor growth and lymph node metastasis of human breast carcinoma MDA-MB-231 cells. Cancer Res 67:11721-11731

19. D'Aquilio F, Procaccini M, Izzi V, Chiurchiu' V, Giambra V, Carotenuto F, Di Nardo P, Baldini PM (2007) Activatory properties of lysophosphatidic acid on human THP-1 cells. Inflammation 30(5):167-177

20. Zhang C, Baker DL, Yasuda S, Makarova N, Balazs L, Johnson LR, Marathe GK, Mcintyre TM, Xu Y, Prestwich GD, Byun HS, Bittman R, Tigyi G (2004) Lysophosphatidic acid induces neointima formation through PPARgamma activation. J Exp Med 199(6):763-774

21. Chang CL, Lin ME, Hsu HY, Yao CL, Hwang SM, Pan CY, Hsu CY, Lee H (2008) Lysophosphatidic acid-induced interleukin-1 $\beta$ expression is mediated through $\mathrm{Gi} / \mathrm{Rho}$ and the generation of reactive oxygen species in macrophages. J Biomed Sci 15. doi: 10.1007/s11373-007-9223-x

22. Ridker PM, Stampfer MJ, Rifai N (2001) Novel risk factors for systemic atherosclerosis: a comparison of c-reactive protein, fibrinogen, homocysteine, lipoprotein(a), and standard cholesterol screening as predictors of peripheral arterial disease. JAMA 285:2481-2485

23. de Macedo Braga LM, Lacchini S, Schaan BD, Rodrigues B, Rosa K, De Angelis K, Borges LF, Irigoyen MC, Nardi NB (2008) In situ delivery of bone marrow cells and mesenchymal stem cells improves cardiovascular function in hypertensive rats submitted to myocardial infarction. J Biomed Sci 15. doi: 10.1007/s11373-008-9237-z

24. Ross R (1999) Atherosclerosis—an inflammatory disease. N Engl J Med 340:115-126

25. Yeh JL, Liou SF, Chang YP, Lin SW, Liu TS, Wu BN, Chen IJ, $\mathrm{Wu}$ JR (2008) Isoeugenodilol inhibits smooth muscle cell proliferation and neointimal thickening after balloon injury via inactivation of ERK 1/2 pathway. J Biomed Sci 15. doi: 10.1007/s11373-008-9236-0

26. Mori T, Ito S, Narita M, Suzuki T, Swaguchi T (2004) Combined effects of psychostimulants and morphine on locomotor activity in mice. J Pharmacol Sci 96:450-458

27. Chiu CT, Ma T, Ho IK (2005) Attenuation of methamphetamineinduced behavioral sensitization in mice by systemic administration of naltrexone. Brain Res Bull 67:100-109

28. Lan KC, Ma T, Lin-Shiau SY, Liu SH, Ho IK (2008) Methamphetamine-elicited alterations of dopamine- and serotoninmetabolite levels within $\mu$-opioid receptor knockout mice:a microdialysis study. J Biomed Sci 15. doi:10.1007/s11373-0079218-7

29. Motawi TK, Abd Elgawad HM, Shahin NN (2008) Gastroprotective Effect of Leptin in Indomethacin-Induced Gastric Injury. J Biomed Sci 15. doi:10.1007/s11373-007-9227-6 